\title{
Imperialism and Accountability in Corporate Law: The Limitations of Incorporation Law as a Regulatory Mechanism
}

\author{
NICHOLAS H D FOSTER ${ }^{*}$ \\ JANE BALL ${ }^{* *}$
}

INTRODUCTION $^{1}$

The most powerful type of group of modern times is the nation-state. However, since its inglorious heyday in the late $19^{\text {th }}$ and early $20^{\text {th }}$ century, its highly autonomous nature has been curbed, externally through the role played by numerous international organisations, internally through the decline in popularity of insular protectionism and the socialist/communist need to centralise control in the state apparatus, as well as by the growth of other centres of power. One such centre of power is the corporation. According to the title of one book, they are 'imperial', ${ }^{2}$ according to another, they might rule the world. ${ }^{3}$ Shell Nigeria acts in some ways like a government, spending over $\$ 50$ million per year in infrastructure projects, consulting those affected by its activity in order to ensure, if not its

\footnotetext{
${ }^{*}$ School of Oriental and African Studies, University of London.

${ }^{* *}$ University of Sheffield.

${ }^{1}$ The literature regarding the accountability of corporations is large and growing larger. References have been kept to a minimum. More can be found in DM Branson 'The Social Responsibility of Large Multinational Corporations' (2002) 16 Transnational Lawyer 121.

${ }^{2}$ RJ Barnet and J Cavanagh, Global Dreams: Imperial Corporations and the New World Order (New York, Touchstone, 1995).

${ }^{3}$ DC Korten, When Corporations Rule the World, 2nd Edition (San Francisco, Berrett-Koehler Publishers, 2001).
} 
popularity, its acceptance. ${ }^{4}$ Total sales of the top 20 corporations are more than US\$1,600 billion and they employ more than 5 million people. ${ }^{5}$

This power should not be exaggerated. Contrary to what some commentators seem to imply, particularly when they draw up tables showing corporations as having more economic weight than many countries: 'States remain sovereign. They wield legal powers that no individual or corporation can possess. ${ }^{6}$ Shell Nigeria's activities are exceptional. They are only undertaken because of the particular capacity problems of the Nigerian state. Shell cannot possibly take over all state functions, nor would its management wish to do so.

It remains true, though, that corporations can exercise great power. In accordance with the general principle of checks and balances in society, that power needs to be kept within bounds. One type of law which states use for the purpose of such control is the law which gives the corporation legal life, its 'incorporation law'. It is a reasonably obvious choice, since it is the law which determines the parameters of the corporation's existence. ${ }^{7}$ However, in a globalised world, states may find their ability to use this type of law seriously curtailed, with many corporations able to evade it with relative ease.

This chapter is mainly concerned with the extent to which corporations can practise such evasion and briefly considers the possibility of an alternative approach.

\footnotetext{
${ }^{4}$ Shell, Social Investment Overview, available at http://www.shell.com (visited 13 May 2003); Shell SPDC 2002 Integrated Environment \& Community Development Stakeholders' Workshop Action Close - Out Report (Shell, 2003).

${ }^{5}$ UNCTAD World Investment Report 2001: Promoting Linkages (New York: United Nations, 2001), cited in H Kovach, C Neligan, and S Burall, Power without Accountability? The Global Accountability Report 1 (One World Trust, 2003) at 15. For more details, see A Dunlop, ‘Corporate Governance and Transnational Corporations’ in this volume.

${ }^{6}$ G Soros, The Crisis of Global Capitalism: Open Society Endangered (London, Little, Brown and Company, $1998)$ at 109.

${ }^{7}$ On the numerous other mechanisms which can be used for this purpose, see, for example, H Ward Legal Issues in Corporate Citizenship (London, Globalt Ansvar - Swedish Partnership for Global Responsibility, 2003).
} 


\section{FACILITATION AND CONTROL}

For our purposes, incorporation law can be considered as having two aspects. The first is its facilitative capacity, giving the grouping its legal form and the legal mechanisms which enable it to function. The second is its ability to regulate the corporation.

Until the recent growth in the importance of the corporation, these aspects received relatively little attention outside the sphere of company law. Far more attention was paid to similar concepts in the context of the nation state, in which facilitative and regulatory concepts evolved slowly over time in well-known ways, varying from state to state, with much interchange of ideas between countries. Notably there emerged the idea of an entity distinct from the person of the monarch, 'the State' or 'the Crown'. ${ }^{8}$ Control evolved in tandem, also over long periods and with much difficulty, including violent upheavals such as the Wars of the Three Kingdoms $1639-1651^{9}$ and the French Revolution 1789. A greater role for assemblies led to the concept of different entities within the state, such as 'the King/Queen in Parliament', 'the judiciary' and 'the executive', as well as to the separation of those entities from each, with the executive being, in theory, supervised and controlled by the other two. Political control came to be exercised by the participants in the state through their representatives. Legal control came to be exercised by the judges.

The history of the corporation is quite different. Despite the fact that it has deep historical roots, with evidence of 'company' type contracts reaching back to the ancient Near East, and some corporations such as the East India Company having state-like powers, its general significance did not match that of the state for centuries. For this reason, facilitative

\footnotetext{
${ }^{8}$ See, for example, J-M Carbasse, Manuel d'introduction historique au droit (Paris, Presses universitaires de France, 2002) at 153; EH Kantorowicz, The King's Two Bodies: A Study in Mediaeval Political Theology (Princeton, Princeton University Press, 1957).

${ }^{9}$ More commonly, if inaccurately, known as 'the English Civil War'. See N Davies, The Isles: A History, (London, Macmillan, 1999) at 490.
} 
concepts were slow to develop beyond such ancient ideas as the commenda contract/company on the European mainland (a kind of limited partnership, in which one party contributed capital and the other commercial expertise, the investor's liability in the venture being limited to the capital contributed; it gave rise to statutory equivalents in civilian legal systems) and the more recent, if still venerable, trust in England. ${ }^{10}$

It was only after the Industrial Revolution, when advances in technology allowed and required the mass concentration and exploitation of resources, that the corporation became a major force. Without wishing to minimise the importance of the long history during which the component ideas were developed, it is not too inaccurate to point to this period as the turning point in facilitative ideas, because it is when the major such idea, incorporation, was made easily available to the general population by simple registration. ${ }^{11}$

On the regulatory side the nation-state was concerned to submit corporations to its control and prevent them from threatening the power of the state by becoming 'independent commonwealths within the kingdom' ${ }^{12}$ An important method used in the taming process was the assumption by the nation-state of the leading role in giving legal form to corporations. In the common law, one way of achieving this was the reservation to the state of the grant of

\footnotetext{
${ }^{10}$ For a history of the commenda and its relationship to other similar contracts, see JH Pryor 'The Origins of the Commenda Contract', (1977) 52 Speculum 5. On companies as contracts and in particular the French approach to this issue, see NHD Foster 'Company Law Theory - England and France' (2000) 48 American Journal of Comparative Law 573-621 at 585-6 and 596-600.

${ }^{11}$ The first significant enactment in the UK was the Joint Stock Companies Act 1844. Limited liability was introduced after many debates by the Limited Liability Act 1855. Much of what we think of as characteristic of the UK company was introduced later, by the Joint Stock Companies Act 1856. In France the Code Civil of 1804 and the Commercial Code of 1807 made very little provision for companies. The first extensive regulation was contained in the Law of 24 July 1867, Art 21 of which was the first provision allowing sociétés anonymes to be formed without specific authorisation of the Conseil d'Etat. Corporate legislation was passed by various states of the United States throughout the early to mid-19 ${ }^{\text {th }}$ century, starting with New York in 1811.

${ }^{12}$ Sir Robert Sawyer, the Attorney-General, in proceedings in 1682 (8 ST 1039), cited in W Holdsworth A History of English Law, 3rd Edition (London, Methuen, 1924) Vol 9 at 46.
} 
legal personality (the 'concession theory'); in French law legal personality is granted by caselaw, but in practice registration is a pre-requisite to this recognition as far as companies are concerned. ${ }^{13}$ Whatever the theoretical method used, the state gave itself the power to impose restrictions on corporations by incorporating those restrictions into the very structure of their legal existence.

\section{THE ENTERPRISE, THE LEGAL ENTITY AND THE MISMATCH}

There are, however, fundamental problems with the approach to regulation just described. In order to understand them it is necessary to understand the nature of the corporation, the way in which it takes legal form, and the separation which took place between the real-world grouping (which will be called, from this point on, the 'enterprise') and the legal construct which was created in order to give it legal standing (the 'legal entity').

\section{The Enterprise}

The enterprise is what the lay person thinks of as the corporation, in other words (roughly speaking) a group of people acting with a common purpose for commercial gain. Examples of such groups are IBM, Microsoft and Shell. Space does not permit a detailed ontological analysis. Suffice it to say that it can be regarded as a unit for everyday purposes, despite being made up of various human and other components. This approach is justifiable because the group has a kind of reality, constituted by a difference between the outcomes possible with a coordinated group and those which are possible with an uncoordinated collection of

\footnotetext{
${ }^{13}$ Cass civ 2e 28 janv 1954: D1954, 2, 217, note Levasseur: 'la personnnalité civile n'est pas une création de la loi, qu'elle appartient, en principe, à tout groupement pourvu d'un possibilité d'expression collective pour la défense d'intérêts licites, dignes, par suite, d'être juridiquement reconnues et protégés.'
} 
individuals. The outcomes are of two types, internal and external. Internal outcomes are manifested by the changed behaviour of the participants in the enterprise. External outcomes are manifested by the effects which the group actions of the enterprise produce on the rest of the world.

Figure 1: The Enteprise ${ }^{14}$

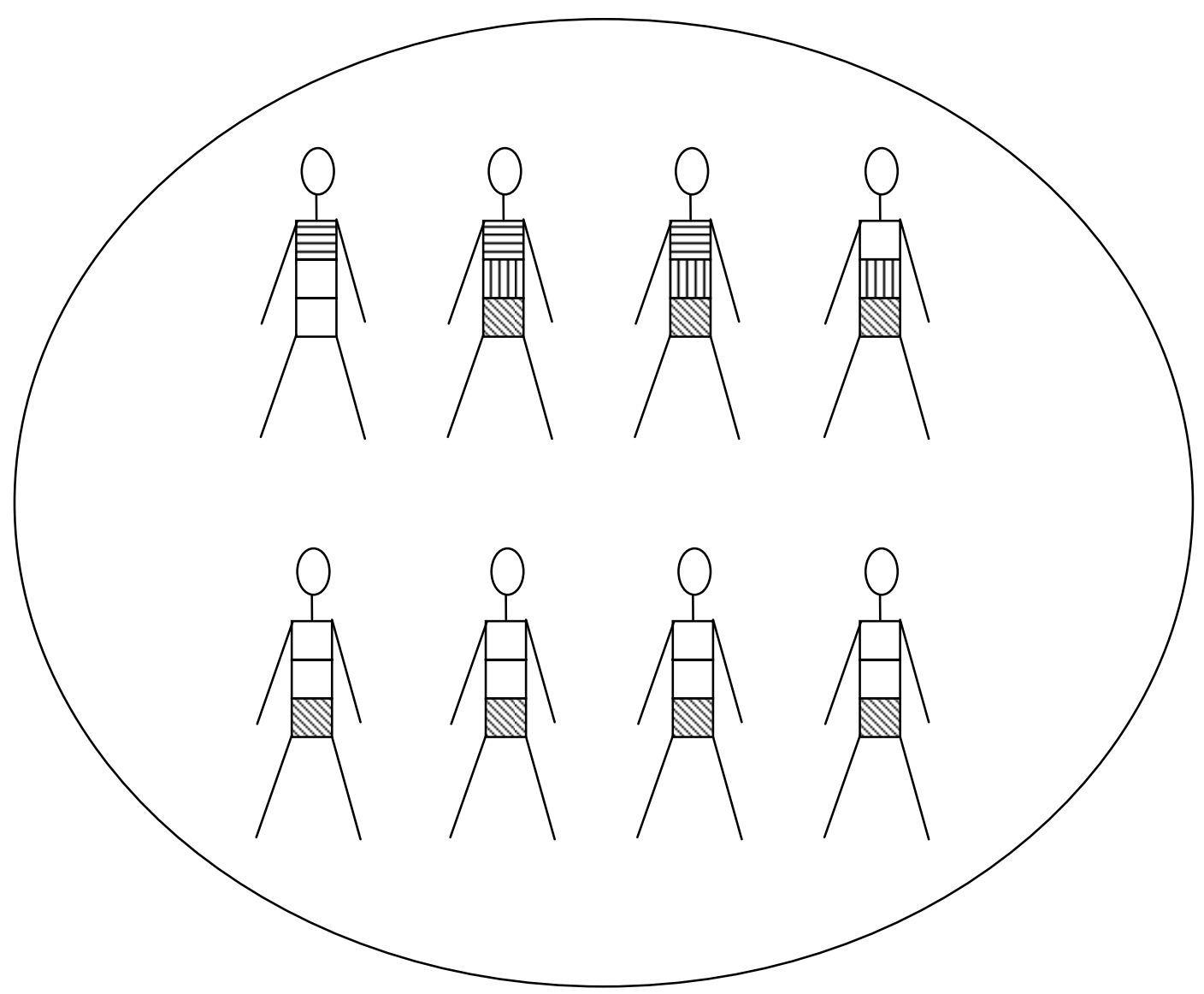

In order to avoid complication, the relationships between the participants are not shown. The shading represents a role which that person has in the organisation. Those people with horizontal lines have contributed capital. Those with vertical lines are managers. Those with diagonal lines are employees. Note that one person can combine various roles.

\footnotetext{
${ }^{14}$ Thanks are due to a traveller on the 1845 Victoria to Epsom train for his comments on the diagram.
} 
The Legal Entity

The legal entity has a different reality. Unlike the enterprise, which is composed of parts which have a physical existence, the legal entity is a pure abstraction with no physical parts, an invention of the law. It has a certain reality which, like that of the enterprise, derives from a difference in outcomes as between its 'existence' and 'non-existence'. With the legal entity, though, the difference is determined by the law. If the law determines that 'a company exists', this in fact means that the participants in 'the company' have different rights and obligations from those which they would have had if 'the company did not exist'. In other words, going through the formalities of 'company formation' results in different legal outcomes for the participants than those which would have obtained if the formalities had not been observed. Examples of the legal entity include IBM United Kingdom Holdings Limited, Microsoft System Sales UK Limited and Shell \& BP Services Limited.

In the legal entity the messiness of the enterprise is artificially tidied up. The roles of the participants are referred to in the language of the legal entity as if they were people ('shareholders', 'directors' and 'employees'). Different rights and obligations are assigned to those roles. The legal entity can be represented as follows. 


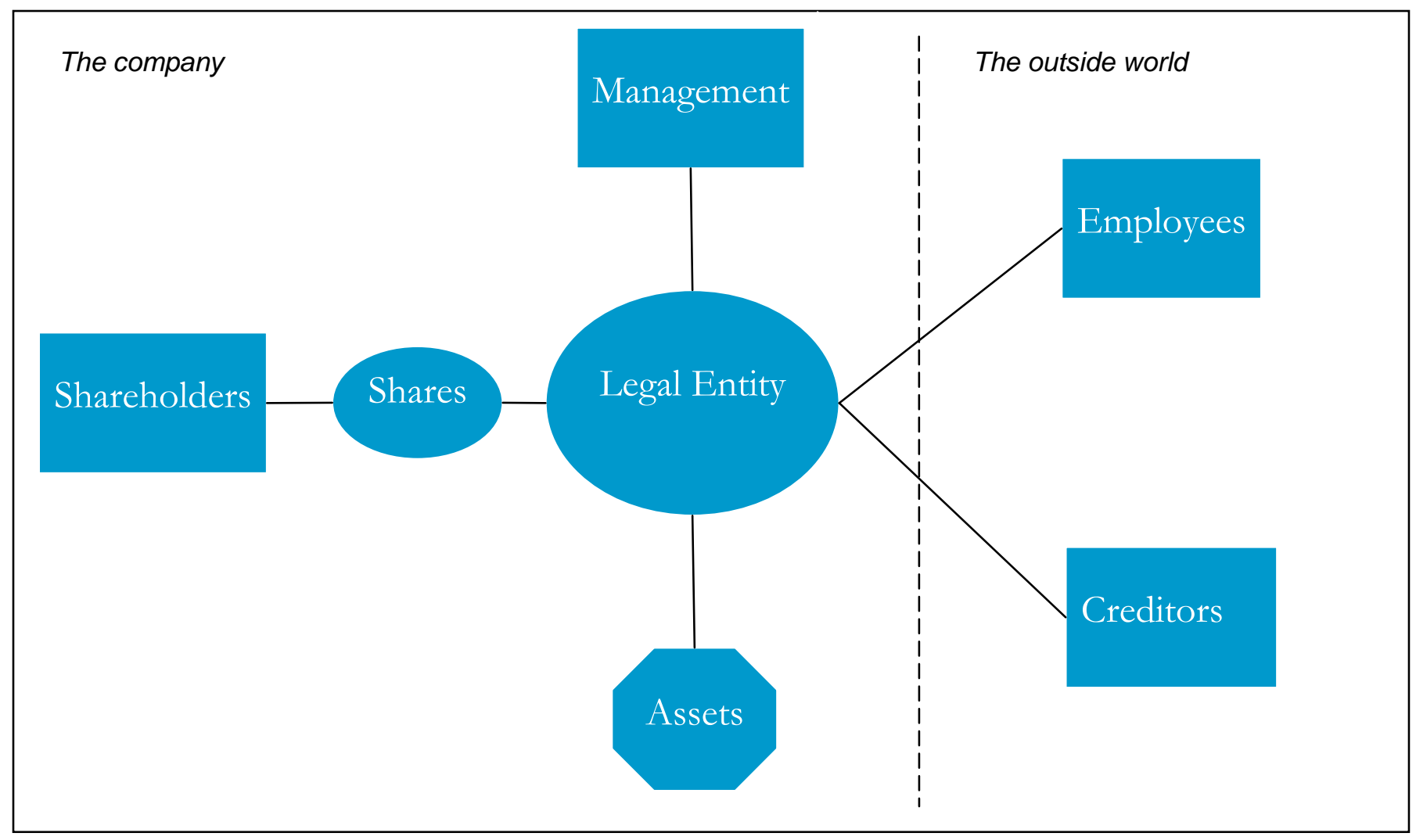

Rectangles denote roles, the concept of the legal entity is represented by the circle. that of shares by an oval. This diagram is based on an English company, hence the position of the employees and the relationship of the company to the assets. In other jurisdictions the employees would be well to the left of the dotted line.

The difference between the reality of the enterprise and that of the legal entity resulted in a split between the two. The legal entity, originally designed to be the legal clothing of the enterprise, can be used simply to alter the legal relationships between individuals who 'form a company' as amongst themselves and as between them and other individuals in the complete absence of any underlying enterprise. To take the example of a company with limited liability, I can form a single shareholder company which borrows $£ 100$ from you. Effectively, I have borrowed the money, there is nobody else involved in the company and there is no enterprise behind it. However, so long as there are no circumstances 
present which might allow the 'veil of incorporation' to be lifted, if the company fails to pay you, I am not liable. ${ }^{15}$

\section{The Mismatch}

Once the distinct and separate nature of the legal entity was realised, it became possible to create the various types of legal entities which we have today, disconnected (either wholly or partially) from any real enterprise, entities which we call 'subsidiaries', 'dormant companies', 'off-the-shelf companies' and so on. This is not to say that there is no link between enterprises and legal entities. Most enterprises act through one or more legal entities and many legal entities are connected in some way to an enterprise.

A consequence of the difference in the natures of the two phenomena is the difference in their relationship to the nation-state.

The legal entity is a creation of the law, that is, of a jurisdiction, therefore its nature is inevitability jurisdictional, therefore national or sub-national. ${ }^{16}$ As the European Court of Justice put it: 'unlike natural persons, companies exist only by virtue of the national legal system which governs their incorporation and operation. ${ }^{, 17}$

\footnotetext{
${ }^{15}$ It is this dichotomy between the reality of the enterprise and the reality of the legal entity which is at the heart of Salomon v A Salomon \& Company, Limited [1897] AC 22, HL(E). See in particular the arguments of counsel at 27, where he refers to the desire of Aron Salomon: 'to convert his unlimited into a limited liability.'

${ }^{16}$ Although not strictly correct, the word 'national' has been used here in preference to 'municipal' to denote the law of a jurisdiction, since the impetus for corporate regulation comes from the nation-state, and 'municipal' could be construed as referring to a sub-division of the nation-state.

${ }^{17}$ Überseering BV v Nordic Construction Company Baumanagement GmbH C208/00, ECJ at §18, citing The Queen v Treasury and Commissioners of Inland Revenue, ex parte Daily Mail and General Trust [1988] ECR 5483, ECJ. A legal entity can, of course, have a link with another jurisdiction if its human actors conduct activities there.
} 
The enterprise, though, is only artificially definable by reference to a nation-state. As the privatising governments of the Thatcher era discovered, in a globalised world without foreign exchange, ownership, or management restrictions, capital has neither nationality nor passport, and management can be of any nationality, as can employees. So enterprises are essentially non-national:

For business purposes the boundaries that separate one nation from another are no more real than the equator. They are merely convenient demarcations of ethnic, linguistic and cultural entities. ${ }^{18}$

\footnotetext{
${ }^{18}$ A former IBM executive, quoted in T Nairn, 'Internationalism and the Second Coming', (1993) 122 Daedalus 155 at 157, quoted in turn in L Cao, 'Corporate and Product Identity in the Postnational Economy: Rethinking U.S. Trade Laws’, (2002) 90 California Law Review 401 at 403.
} 
The non-national nature of the enterprise can be roughly represented as follows.

Figure 3: The Relationship of the Enterprise to Jurisdictions.

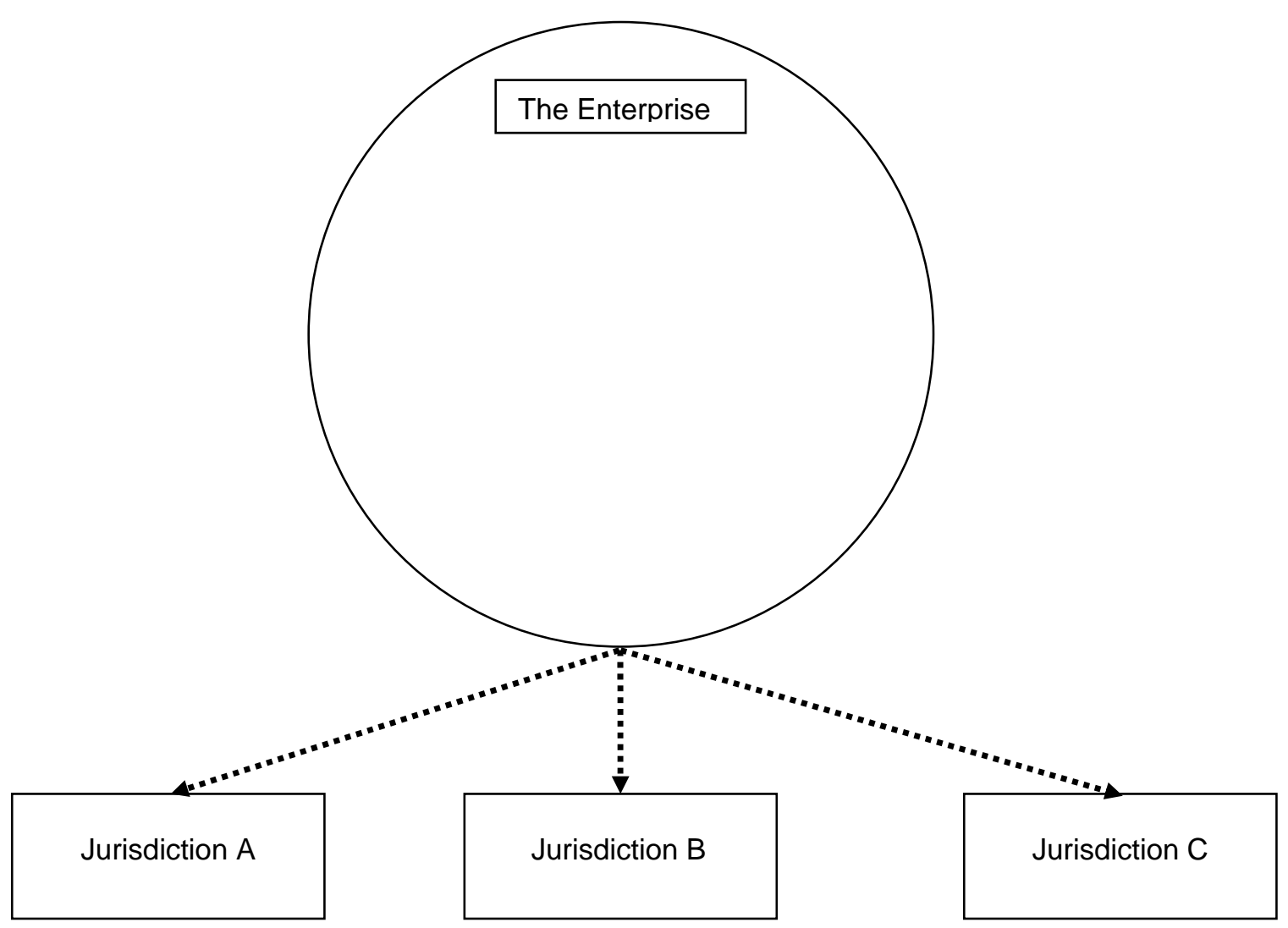

The dotted lines indicate some real-world link to the jurisdiction in question, such as a business activity in that place.

The link between a legal entity and its jurisdiction can be represented as follows. 
Figure 4: The Relationship of the Legal Entity to its Jurisdiction of Incorporation

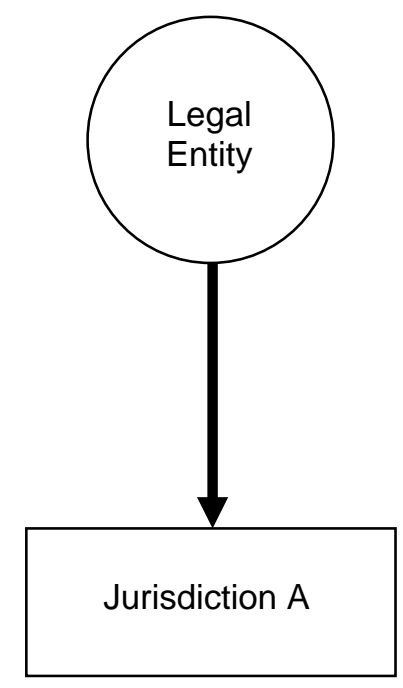

The thick line represents the legal link to the jurisdiction of incorporation, the jurisdiction which gives it existence. A legal entity can, of course, have a link with another jurisdiction if its human actors conduct activities there. This can be represented as follows.

Figure 5: The Relationship of the Legal Entity to its Jurisdiction of Incorporation and other Jurisdictions

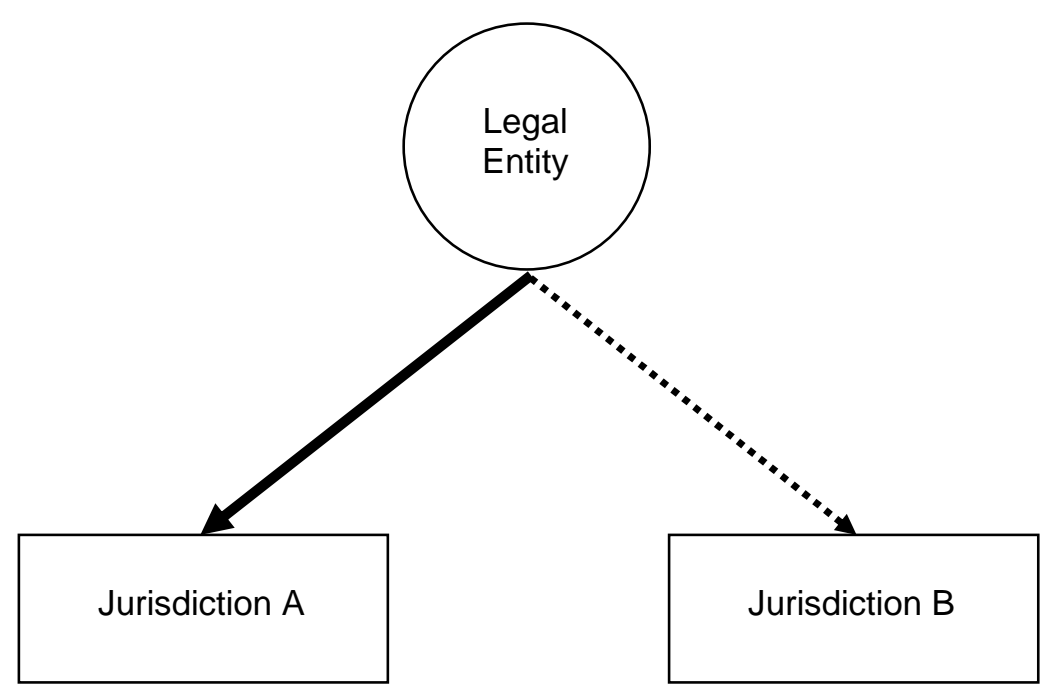


The dotted line represents a real world connection to another jurisdiction.

Since most enterprises use legal entities as their legal representation, a more accurate picture is given by combining Figures 4 and 5, as set out below (Figure 6). In this diagram, the dotted lines represent a real-world connection of some sort, which in the case of the enterprise passes through the legal entities.

Figure 6: The Relationship of the Enterprise and its Legal Entity to Jurisdictions.

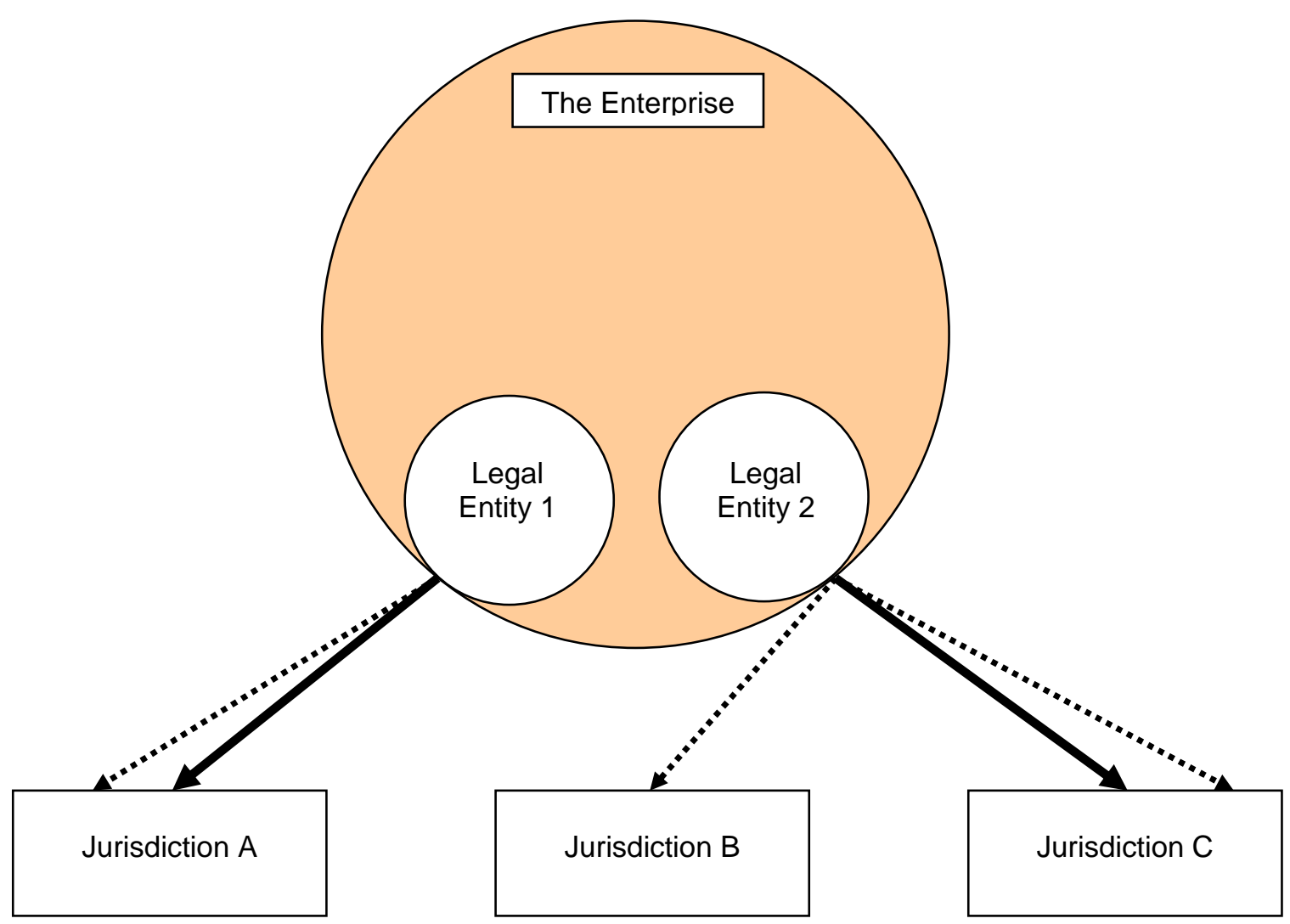

The fact that the enterprise is non-national and the legal entity national poses a regulatory problem. Enterprises can in theory choose their incorporation law, and therefore the degree of control exercised by it, so long as they can find a 'host' jurisdiction prepared to allow them to incorporate in that jurisdiction. 
The ability of an enterprise to shop around in this way should not be exaggerated. If it wishes to incorporate, it must choose at least one jurisdiction in which to do so, and sometimes will be obliged, either by legal or commercial constraints, to be represented by a legal entity in a jurisdiction with a more onerous incorporation law than it would wish. However, the possible consequences of the evasion of incorporation law regulation by choice of incorporation jurisdiction do merit consideration.

\section{VARIETIES OF NATIONAL CONTROL}

Since corporate regulation effected by incorporation law is still national, it can vary quite significantly from one jurisdiction to another. These variations derive from different conceptions of the role of groups in general and the role of enterprises in particular, and result in incorporation law regimes of two main types: the Civilians and the Commoners. The Civilians and the Commoners, tracing their ancestry respectively, in the first instance, to France and England, and at a later stage influenced by German and United States ideas, inhabit two different mental, cultural and ideological worlds. ${ }^{19}$

We must be careful not to exaggerate the differences between the two traditions, for both include a high degree of regulation. However, those differences are significant, it being fair to say, as a broad generalisation, that the common law conception of the enterprise is of

\footnotetext{
${ }^{19}$ A few Neutrals, such as China, pick and choose. For an overview of company law worldwide, see C Jordan, An International Survey of Companies Law in the Commonwealth, North America, Asia And Europe (London, DTI, 1998). On its spread, see K Pistor, Y Keinan, J Kleinheisterkamp and MD West, ‘The Evolution of Corporate Law: A Cross-Country Comparison’, (2002 ) 23 University of Pennsylvania Journal of International Economic Law 791. The efficacy of transplanting company law is not discussed herein. On this issue, see, for example, (on Russia) B Black and R Kraakman, ‘A Self-Enforcing Model of Corporate Law’, (1996) 109 Harvard Law Review 1911; (Slovakia, China and Vietnam) C Jordan, Law Matters: Corporate Governance Law Reforms (2000), available at: http://www.worldbank.org/wbi/corpgov/core_course/core_pdfs/jordan_lawmatters.ppt.
} 
an essentially private grouping while the civilians view it as quasi-public. ${ }^{20}$ These divergent conceptions of the role of the enterprise in society give us different conceptions of the enterprise itself.

In the common law world, private interests should be allowed free rein unless there are pressing reasons to restrict them. In particular, primacy is given to the private interests of the investors/'owners'.

In the civilian tradition, it is more important to protect public than private interests. The enterprise is viewed as part of a regulated economy in which one of its functions is to provide social benefits, such as employment, for citizens. ${ }^{21}$ Notably, many civilian systems have: some attempt to ensure that legal entities have an enterprise, or something resembling it, underlying them, notably by imposing minimum capital requirements (intended to ensure that the underlying enterprise is properly capitalised, thereby protecting creditors from the risks of an insufficiently funded venture); a recognition criterion based on the place of activity rather than on the place of incorporation (the doctrine of the 'seat', based on the assumption that the attempt to ensure that there is an enterprise underlying the legal entity has worked); ${ }^{22}$ and extensive involvement and protection of employees.

\footnotetext{
${ }^{20}$ The words 'public' and 'private' need some clarification. 'Private' means that the legal system considers the company to concern only the individuals who make it up, much as a contract is normally considered to concern the parties to it, and not others; 'public' means that the legal system considers the company as constituting a powerful body which can affect non-participants, and therefore has a responsibility to those non-participants and a need to be controlled. The words are not to be taken in their French technical legal sense, in which companies are private law institutions, as opposed to public law legal persons such as the state, hospitals and universities.
}

For the US literature, see A Wolfe, ‘The Modern Corporation: Private Agent or Public Actor?’ (1993) 50 Washington and Lee Law Review 1673 at 1673-74. On the different ideologies of public and private law, see J W Singer, 'The Legal Rights Debate in Analytical Jurisprudence from Bentham to Hohfeld', (1982) Wisconsin Law Review 975 at 982-83.

${ }^{21}$ On the different approaches of the common law and civilian traditions to economic freedom, see PG Mahoney, 'The Common Law and Economic Growth: Hayek Might Be Right', (2001) 30 Journal of Legal Studies 503.

${ }^{22}$ For a discussion of the different recognition theories, see R Drury, 'The Regulation and Recognition of Foreign Corporations: Responses to the Delaware Syndrome’, [1998] CLJ 165 at 168-75. 
The doctrine of the seat needs some more explanation. ${ }^{23}$ There is considerable variation among those jurisdictions which have it. Only Germany and France will be examined here.

In France, Art 1837 Civil Code provides that companies which have their seat on French territory are subject to French law. The seat must be 'real', and this reality will be determined by the court. For example, if the French court comes to the conclusion that a seat abroad is a sham, and that the real seat is in France, it will apply French law. This is supposed to permit policing of companies by criminal penalties, since those penalties are only effective if the seat is in the jurisdiction in which the penalties are imposed. In Germany, the legal capacity of a company is determined by the law of the place where its administration is established, its seat. In order to enjoy legal capacity a company which transfers its administration to Germany must be reincorporated in Germany. ${ }^{24}$ The doctrine:

prevents the provisions of company law in the State in which the actual centre of administration is situated, which are intended to protect certain vital interests, from being circumvented by incorporating the company abroad. ${ }^{25}$

Other systems (notably those of the common law, but a few civilian systems have similar attitudes in some areas), take a different view. English law, for example, is not concerned to ensure that the legal entity has any significant 'reality' in the sense of there being a substantial enterprise underlying it, so long as the formal minimum requirements are

\footnotetext{
${ }^{23}$ See PJ Omar, 'Centros Revisited: Assessing the Impact on Corporate Organisation in Europe’, (2000) 11 ICCLR 407 at 408; PJ Omar, 'Centros Redux: Conflict at the Heart of European Company Law’, (2002) 13 ICCLR 448 at 449-50 and The High Level Group of Company Law Experts A Modern Regulatory Framework for Company Law in Europe: A Consultative Document of the High Level Group of Company Law Experts (Brussels, European Union, 2002) at 32-34.

${ }^{24}$ Per the ECJ in Überseering BV v Nordic Construction Company Baumanagement GmbH C208/00, ECJ at §5.

${ }^{25}$ Per the ECJ in Überseering BV v Nordic Construction Company Baumanagement GmbH C208/00, ECJ at §16.
} 
met (one person who acts as a member/director and one person who acts as a secretary, the filing of accounts and other documents, etc). ${ }^{26}$ Nor does it base any control mechanism on any requirements for, or assumptions about, such a reality. A prime example of this attitude is the complete absence of any minimum capital requirement for private companies. Recognition of foreign legal entities is based on their place of incorporation and there is no concept of the seat, let alone any attempt to use such a concept to regulate the enterprise by ensuring that the legal entity is subject to the control of the incorporation law of the jurisdiction concerned. There is little, if any, employee participation or protection. These attitudes result in considerable advantages for the incorporator. In England and Wales, for example:

the shares do not have to be fully paid up, formation is much quicker, no prior examination of the constitution is necessary and the conditions governing the amendment of the constitutive documents, the transfer of shares and publicity are less strict. $^{27}$

Having reached this point, a qualification of what has just been said is necessary. The divide between common law and civilian law is very rough, for there is considerable variation. For example, of the civilian jurisdictions in the European Union, Denmark, Finland, the Netherlands and Sweden do not have the 'seat' doctrine. ${ }^{28}$ Germany has a group liability concept which is useful for the protection of other stakeholders, but which is not found elsewhere. $^{29}$

\footnotetext{
${ }^{26}$ All of these can be corporate bodies, in which case the 'reality' underlying the legal entity is tenuous.

${ }^{27}$ See Advocate-General Alper’s opinion in Kamer van Koophandel en Fabrieken voor Amsterdam v Inspire Art Ltd C167/01, ECJ at III, 4.

${ }^{28}$ Those which do have it include Austria, France, Germany and Luxembourg: PJ Omar, 'Centros Revisited: Assessing the Impact on Corporate Organisation in Europe’, (2000) 11 ICCLR 407 at 407.

${ }^{29}$ See J Peter, 'Parent Liability in German and British Law: Too Far Apart for EU Legislation?’ (1999) European Business Law Review 440.
} 


\section{RACING TO THE BOTTOM? CENTROS, ÜBERSEERING AND INSPIRE ART ${ }^{30}$}

The mismatch between (i) the non-national nature of the enterprise and (ii) its local legal manifestation, combined with the new extension of the freedom of the enterprise to pick and choose jurisdictions, could eventually lead to the predominance of the attitudes of one model of incorporation law, or at least to a considerable conflict between those models.

In the United States, the mismatch between states and enterprises famously led to a 'race to the bottom', in which state legal systems competed for incorporation and other business by attempting to provide the corporate law regime which is most attractive to incorporators, a race won by Delaware. ${ }^{31}$ The United States model is interesting, but evolved as a result of competition among very similar common law systems. More pertinent, perhaps, are the Centros, Überseering and Inspire Art cases, which provide, in the exaggerated setting of a legal right to establishment granted by European Union law, examples of a direct confrontation between common law and civilian concepts.

All the cases concerned Art 43 and 48 EC Treaty. Pursuant to these articles, companies enjoy the same freedom of establishment within the European Economic Area as individuals, and Member States may not restrict that freedom (with limited exceptions). To

\footnotetext{
30 Centros Ltd v Erhvervs- og Selskabsstyrelsen C212/97 [2000] Ch 446, ECJ; Überseering BV v Nordic Construction Company Baumanagement GmbH C208/00, ECJ; Kamer van Koophandel en Fabrieken voor Amsterdam v Inspire Art Ltd C167/01, ECJ. Numerous commentaries on the Centros case include P J Omar, 'Centros Revisited: Assessing the Impact on Corporate Organisation in Europe', (2000) 11 ICCLR 407; commentaries on the Überseering case include W H Roth, 'From Centros to Ueberseering: Free Movement of Companies, Private International Law, and Community Law', [2003] ICLQ 177 and E Micheler, 'Recognition of Companies Incorporated in Other EU Member States', [2003] ICLQ 521, in which the Inspire Art case is also discussed; a casenote on the Inspire Art case is H De Wulf and S Dejonghe, 'Netherlands Company Law Corporate Seats' (2004) 15 ICCLR N29-30. See also Commission of the European Communities v Portugal Case C-171/02, ECJ, Apr 29, 2004, in which a minimum capital requirement for security firms wishing to set up business in Portugal was found to be in breach of Art 43 EC ( $\$ 54$ of the judgment).

31 The principal issues are discussed in ME Eisenberg, 'The Structure of Corporation Law', (1989) 89 Columbia Law Review 1461 at 1505-14.
} 
qualify, companies must have one or more of their place of incorporation, principal place of administration, or principal place of business, in a Member State, and must be set up to make a profit.

In the Centros case, two Danish nationals and residents incorporated Centros Limited in England and Wales with a nominal capital of $£ 100$, which was not paid up. The company applied to set up a branch in Denmark. The Danish Trade and Companies Board refused the application on the grounds that the only reason for incorporating the company in England and Wales was to avoid the onerous minimum capital requirements of Danish law (DKK200,000, about $€ 27,000$ or $£ 19,300$ at the time of writing). On a reference by the Danish Supreme Court to the European Court of Justice for a preliminary ruling, the ECJ held that the motive did not remove the company's right to freedom of establishment.

The Centros case concerned capital requirements, not the seat, although it seemed to many that the demise of the doctrine was an inevitable consequence of the decision. The Überseering case did directly raise the question of the seat. Überseering BV ('Überseering'), incorporated in the Netherlands, owned buildings in Germany. In 1992 Überseering engaged a German company, Nordic Construction Company Baumanagement GmbH ('Baumanagement') to renovate the buildings. In 1994 two German nationals and residents acquired all the shares in Überseering. Überseering was dissatisfied with the standard of work and sued Baumanagement in 1996, alleging breach of contract.

The German courts reasoned as follows: the legal capacity of a company is determined by the law of the place where its administration is established; the acquisition of the shares by the German nationals meant that the administration of Überseering was transferred to Germany; hence its legal capacity was determined by German law; under German law, in order to enjoy legal capacity a company which transfers its administration to Germany must be reincorporated in Germany; ${ }^{32}$ and Überseering had not been reincorporated in Germany. Therefore it did not have legal capacity in Germany.

\footnotetext{
${ }^{32}$ Per the ECJ in Überseering BV v Nordic Construction Company Baumanagement GmbH C208/00, ECJ at §5.
} 
The ECJ, however, held that this conclusion was contrary to the principle of freedom of establishment, despite the German government's arguments that the seat doctrine protected creditors (by ensuring a minimum share capital), minority shareholders and employees, and prevented tax evasion. The court did furnish a caveat:

It is not inconceivable that overriding requirements relating to the general interest, such as the protection of the interests of creditors, minority shareholders, employees and even the taxation authorities, may, in certain circumstances and subject to certain conditions, justify restrictions on freedom of establishment.

But the court went straight on to say:

Such objectives cannot, however, justify denying the legal capacity and, consequently, the capacity to be a party to legal proceedings of a company properly incorporated in another Member State in which it has its registered office. Such a measure is tantamount to an outright negation of the freedom of establishment conferred on companies by Articles 43 EC and 48 EC. ${ }^{33}$

The Inspire Art case is of dual interest. Not only does it provide a further example of a common law legal entity being used in preference in a civilian type, it also furnishes us with an instance of possible civilian countermeasures. Inspire Art Limited was incorporated in England and Wales solely in order to benefit from the perceived advantages of English incorporation law over the incorporation law of the Netherlands. The Netherlands legislature had enacted the Pure Form Foreign Companies Act 1997 specifically in order to deal with the phenomenon of such Delaware and English 'pseudo-foreign' companies. ${ }^{34}$ The Act provided

\footnotetext{
${ }^{33}$ At $\S 92$.

${ }^{34}$ See $\S 31$ of the opinion of Advocate General Alper.
} 
that companies with 'no real connection with [their state of incorporation]' (Art 1) had to register as a 'foreign pure form company' (Art 2), publicise this status (Art 3), and comply with the Dutch minimum capital requirements (Art 4). Non-compliance was punishable by the imposition of personal liability on the company directors (Art 4). The ECJ came to the conclusion that:

It is contrary to Articles $43 \mathrm{EC}$ and $48 \mathrm{EC}$ for national legislation ... to impose on the exercise of freedom of secondary establishment in that State by a company formed in accordance with the law of another Member State certain conditions provided for in domestic company law in respect of company formation relating to minimum capital and directors' liability. The reasons for which the company was formed in that other Member State, and the fact that it carries on its activities exclusively or almost exclusively in the Member State of establishment, do not deprive it of the right to invoke the freedom of establishment guaranteed by the EC Treaty, save where the existence of an abuse is established on a case-by-case basis. ${ }^{35}$

In the EU, the ECJ's caveat to its decision in Überseering ${ }^{36}$ may provide an escape route of sorts for the seat doctrine, but it is submitted that the caveat should be read restrictively, and that Paul Omar's description of the effect of the judgement as an 'earthquake in jurisprudential terms in the German-speaking world' will prove to be correct in terms of practice as well. ${ }^{37}$ This seems to be confirmed by the Inspire Art case, since the Dutch court and the German, Dutch and Austrian governments argued specifically that the

\footnotetext{
${ }^{35}$ Kamer van Koophandel en Fabrieken voor Amsterdam v Inspire Art Ltd C167/01, ECJ, Nov 15, 2003, §142.

${ }^{36}$ See footnote 29 above.

${ }^{37}$ PJ Omar, 'Centros Revisited: Assessing the Impact on Corporate Organisation in Europe’, (2000) 11 ICCLR 407 at 407.
} 
Dutch measures contested in Inspire Art were justified by the exception, and this argument was rejected. $^{38}$

More generally, the cases can be interpreted as showing that, in a straight contest between common law and the more protective type of civilian law attitude, the common law has a distinct advantage. Add to this the predominance of United States (and, to a lesser extent, English/UK) ideas in legal globalisation, and the existence of micro-states eager to cash in on any opportunity to gain registration income, legal-organisational bio-diversity seems threatened, as does the long-term survival of a stricter corporate regulatory regime, for:

the company's founding members are placed at an advantage, since they are able, when choosing the place of incorporation, to choose the legal system which suits them best. ${ }^{39}$

In other words, these examples seem to show that attempts to regulate the enterprise using incorporation law on a national level may founder in an environment where enterprises have the freedom to establish themselves elsewhere. In order to avoid any inconvenient regulation all the enterprise has to do is incorporate in another jurisdiction with less restrictive incorporation law. Such a result is one that regulators in both the common law and civilian traditions, whatever their differences concerning the degree and manner of regulation which is appropriate, would presumably wish to avoid.

\footnotetext{
${ }^{38}$ See §63ff and §155(2) of Advocate-General Alper’s opinion, §82, §86 and §§95-99 of the judgment. See also The High Level Group of Company Law Experts, Report of the High Level Group of Company Law Experts on a Modern Regulatory Framework for Company Law in Europe (Brussels, European Union, 2002) at 102: 'for a Member State to adopt a version of the real seat doctrine which automatically denies recognition to a company which has its "real seat" in a country than that of its incorporation was a disproportionate measure which can never be justified' (footnote omitted). Eva Micheler discusses even more wide-ranging possibilities. E Micheler, 'Recognition of Companies Incorporated in Other EU Member States’, [2003] ICLQ 521 at 529.
} 


\section{MATCHING THE REGULATION TO THE REGULATED}

This conclusion may be alarmist, for the degree to which company law can be harmonised worldwide is controversial. In the closely related field of corporate governance, for example, many commentators see considerable cultural resistance to Anglo-Saxon pressures. ${ }^{40}$ It must also be said that, to date, few large enterprises have taken advantage of the possibilities of regulatory evasion. ${ }^{41}$ It is also important to note that, once an enterprise is established in a given jurisdiction it may be difficult, expensive or both to change (to 'migrate'). ${ }^{42}$ However, if it does turn out that common law ideas spread and dominate, which, it is submitted, is at least a distinct possibility, incorporation law may well have serious limitations as a means of corporate regulation in a globalised environment. Two questions then arise:

$>$ Can national non-incorporation law perform the necessary regulatory function?

What role is there for international regulation?

\footnotetext{
${ }^{39}$ Überseering BV v Nordic Construction Company Baumanagement GmbH C208/00, ECJ at §15.

${ }^{40}$ See AN Licht, 'International Diversity in Securities Regulation: Roadblocks on the Way to Convergence', (1998) 20 Cardozo Law Review 227 at 227 (comparing corporate governance to securities market law). But see DM Branson, 'The Very Uncertain Prospect of "Global" Convergence in Corporate Governance’, (2001) 34 Cornell International Law Journal 321.

${ }^{41}$ According to Branson: 'A vexing conundrum has been precisely why so few, if any multinationals have moved to an offshore incorporating state. Scholars have raised the possibility of a "bandit” multinational moving off shore but it seems not to have occurred.' DM Branson, 'The Very Uncertain Prospect of "Global” Convergence in Corporate Governance’, (2001) 34 Cornell International Law Journal 321 at 357. The cases that have come before the European Court of Justice seem to confirm this. However, this is not to say that the issue is irrelevant just because it concerns small enterprises, nor that it could not concern larger enterprises in the future.

${ }^{42}$ On migration within the European Union see J Bisacre, 'The Migration of Companies Within the European Union and the Proposed Fourteenth Company Law Directive’ [2001] ICLQ 251.
} 
As regards the first possibility, similar problems arise to those encountered in incorporation law. The enterprise remains non-national in nature, whereas regulation is territorial. Once again, we must not exaggerate, for the vast majority of enterprises are obliged to operate within jurisdictions in which their activities are highly regulated. But there are many, particularly the largest, which can at least partially evade regulation, for example by moving some functions to low labour cost and low labour regulation jurisdictions.

Deficiencies of national regulation lead naturally to thoughts of international action. However, here too the mismatch between the non-national nature of the enterprise with national regulation causes problems. Even though the term is often used, international regulation is not effective supra (above, or over) nations, and therefore, at least arguably, over everyone and every body/grouping in or across nations, including non-national enterprises. ${ }^{43}$ It is made and enforced inter (among) nations, because the makers of international law, and the components of international organisations, are nation-states. Agreement must come from them and norms must be enforced by them. An international solution would therefore only work if there were to be a very broad, if not worldwide, consensus on the entire content of incorporation law and the conflict of law rules which deal with recognition of legal entities, otherwise an enterprise could simply avoid the regulatory net by incorporating in one of the states not party to the multilateral effort. However, the profound ideological divide between the two traditions constitutes a considerable obstacle to the formation of such a consensus. If decades of concerted efforts have failed to bridge the divide on employee participation in the relatively narrow forum of the European Union, ${ }^{44}$ it is hard to see how agreement could be reached on a broader range of issues on a worldwide basis. ${ }^{45}$

\footnotetext{
${ }^{43}$ Some would argue that European Union law is an exception. Even in this case, however, the law is ultimately based on agreement between member states.

${ }^{44}$ The main, and failed, document was the Draft $5^{\text {th }}$ Directive on Company Law. For a recent instalment of the saga, see the National Works Councils Directive (Directive 2002/14/EC of the European Parliament and of the Council of 11 March 2002 establishing a general framework for informing and consulting employees in the
} 
None of this seems to bode very well for the prospects of the regulation of the enterprise through incorporation law. However, there may be an alternative solution, which can be found by reconsidering the fundamental problem underlying all the possibilities so far considered. The $19^{\text {th }}$ century nation-state based method of using incorporation law to regulate enterprises has led us to a dead end because it attempts to regulate the non-national enterprise by regulating the national legal entity, failing to take into account the mismatch between the natures of the enterprise and the legal entity and the consequences of the mismatch for regulation. It would seem logical, therefore, to abandon vain attempts to regulate A by regulating $\mathrm{B}$, and match the regulation to the regulated by controlling the enterprise directly.

This suggestion poses all sorts of difficulties, given the elusive nature of the enterprise. However, there are indications of a readiness to use this approach, such as the common use of the word 'undertaking' by the European Union, ${ }^{46}$ and it is familiar to accountants, tax lawyers and tax authorities. It has the advantage of dealing with the reality of the situation and of side-stepping at least some of the problems created by existence of two, conceptually different, models of incorporation law. ${ }^{47}$ It is submitted that this method would at least constitute a sound base from which to tackle this admittedly difficult task. It would at

European Community), due to be implemented by March 2005, but which may not be fully implemented in the UK until 2008.

${ }^{45}$ A possible alternative to a binding multilateral agreement is a code of conduct. But reaching agreement could be just as difficult, and even if agreement were reached, it would suffer from an exaggerated form of one of the fundamental problems of regulation: the conscientious abide by regulations, while the ruthless and the sloppy ignore them.

${ }^{46}$ Defined for UK company law use by s 259(1) Companies Act 1985, and linked to the complex definition of a subsidiary in s 258. Other issues that might arise, such as the legitimacy of any international body regulating enterprises, are more problematical. Might corporations invoke a principle of 'no regulation without representation’?

${ }^{47}$ Related thinking is to be found in the idea of the 'Centre of Main Interest' (COMI) contained in Art 3(1) Regulation on Cross-Border Insolvency (Reg 1346/2000) which relies to a considerable extent on the enterprise concept, even if it is in a sense the mirror image of what is proposed, since it determines the legal order applicable for the insolvent legal entity by reference to the activity of the enterprise underlying it. 
least be preferable to relying on the fundamentally flawed idea of the enterprise and the legal entity being inevitably linked. 